Article history: Submitted 3 January 2021; Accepted 18 January 2021; Available online 1 February 2021.

\title{
Kewenangan Kurator Dalam Pemberhentian Direksi Perseroan Terbatas
}

\author{
Clara Renny Kartika \\ clararennyk14@yahoo.co.id \\ Universitas Airlangga
}

\begin{abstract}
Keywords: Abstract
Dismissal of The Board of Directors of a Company as an organ of the Company has responsibility for Director of a the management in a Company, which means that the Company would not exist without Company; Curator's the role of the Directors and vice versa. In the bankruptcy, the Directors of a Company Authority; the Role may be terminated by the General Meeting of Shareholders (GMS) with the approval of the of GMS. Curator that regulated in the constitution of the Company. The curator is not authorized to hold the GMS himself and amends the articles of association without the role of the GMS. The legal consequences of the dismissal of the Board of Directors of a Company have various impacts that will affect the continuity of the business of the company itself or to other shareholders if the dismissal mechanism is not in accordance with applicable regulations even though the effects are not felt directly. If the responsibility that Board of Directors have is relinquished by the dismissal that Curator decided, this can be judged to be ineffective in the management and arrangement of bankrupt assets because the actual organs of the Company where Directors are still needed by the Curator in handling such matters. The Board of Directors of a Company that dismissed by a Curator may take a legal action in the form of other claims against the Curator's actions as well and make a report to the Honorary Board of the Organization of the originator of the Curator regarding the violations of the code of conduct that committed by the Curator.
\end{abstract}

\section{Kata Kunci: $\quad$ Abstrak}

Pemberhentian Direksi Perseroan Terbatas sebagai organ Perseroan memiliki tanggung jawab Direksi Perseroan terhadap kepengurusan Perseroan Terbatas yang mengartikan bahwa Perseroan Terbatas;

Kewenangan Kurator; Peran RUPS. tidak akan ada apabila tanpa peranan Direksi dan begitu pula sebaliknya. Apabila terjadi kepailitan, Direksi Perseroan Terbatas dapat diberhentikan oleh Rapat Umum Pemegang Saham (RUPS) dengan persetujuan dari Kurator yang diatur dalam Undang-Undang Perseroan Terbatas. Kurator tidak berwenang mengadakan RUPS sendiri dan mengubah anggaran dasar tanpa adanya peranan RUPS. Akibat hukum dari adanya pemberhentian Direksi Perseroan Terbatas memberikan berbagai dampak yang mempengaruhi kelangsungan usaha-usaha perusahaan itu sendiri atau terhadap pemegang saham lainnya bila mekanisme pemberhentiannya tidak sesuai dengan ketentuan yang berlaku walaupun tidak dirasakan secara langsung akibat yang ditimbulkannya. Jika Direksi dilepaskan tanggung jawabnya melalui pemberhentian oleh Kurator maka hal ini dapat dinilai terjadi ketidakefektifan dalam pengurusan dan pemberesan harta pailit karena sebenarnya organ Perseroan Terbatas yang mana itu Direksi masih dibutuhkan oleh Kurator dalam penanganan hal tersebut. Direksi Perseroan Terbatas yang diberhentikan oleh Kurator dapat melakukan upaya hukum yang berupa gugatan lain-lain tindakan Kurator serta melakukan pelaporan ke Dewan Kehormatan Organisasi asal Kurator terkait pelanggaran kode etik yang dilakukan oleh Kurator. 


\section{Pendahuluan}

Perseroan Terbatas merupakan badan hukum yang sering digunakan di kalangan masyarakat dan berdiri dengan adanya perjanjian yang dalam hal ini berhubungan erat dengan sifat kontraktual. Unsur-unsur badan hukum yang terdapat dalam UU PT ialah organisasi yang teratur, harta kekayaan sendiri, melakukan hubungan hukum sendiri dan mempunyai tujuan sendiri. ${ }^{1}$ Dalam Perseroan telah diketahui terdiri dari organ-organ penting didalamnya yakni rapat umum pemegang saham (RUPS), Direksi, dan Dewan Komisaris yang memiliki kewenangan dan tugas yang berbeda-beda sebagaimana diatur dalam Pasal 1 angka 2 Undang-Undang Nomor 40 Tahun 2007 tentang Perseroan Terbatas yang selanjutnya disebut UU PT.

Dalam UU PT terdapat aturan yang mengatur bahwa Anggota Direksi bertanggung jawab secara renteng apabila terjadi kerugian di Perseroan, jika tidak terbukti maka tidak akan dituntut pertanggungjawaban atas kerugian yang dialami Perseroan tersebut. Apabila benar terjadinya kepailitan disebabkan oleh kesalahan Direksi, maka Direksi tidak berwenang untuk mengurus harta kekayaannya kembali dan akan menjadi sita umum. Tugas utama Kurator ialah melakukan pemberesan dan pengurusan harta pailit sejak dikeluarkannya putusan pailit terhadap debitor pailit.

Kepailitan yang merupakan sita umum atas semua kekayaan debitor pailit yang pengurusan dan pemberesannya dilakukan oleh Kurator di bawah pengawasan Hakim Pengawas sebagaimana diatur dalam Pasal 1 angka 1 UUK telah memberikan pemahaman bahwa Direksi yang merupakan pengurus utama yang ditunjuk RUPS dalam Perseroan wajib bertanggung jawab apabila Perseroan mengalami kepailitan hanya jika Direksi telah terbukti menyebabkan pailitnya PT maka berlaku tanggung jawab pribadi. Dikarenakan tujuan dari Kurator untuk mengamankan seluruh harta debitor pailit, hal ini tidak berarti Kurator memiliki wewenang melakukan suatu perbuatan hukum di luar ketentuan peraturan

\footnotetext{
1 Abdulkadir Muhammad, Hukum Perusahaan Indonesia (Citra Aditya Bakti 2002).[69].
} 
perundang-undangan. Tugas utama Kurator yang utama tetaplah hanya berpegang dalam melakukan pengurusan dan/atau pemberesan harta pailit.

Jika terdapat Kurator yang memberhentikan Direksi untuk menghindari terjadinya ketidakberesan dalam penanganan harta debitor pailit yang diakibatkan dari kesalahan dan kelalaian dari Direksi, hal ini tidak dapat dimungkinkan terjadi mengingat tugas Kurator hanya terbatas sampai pengurusan dan pemberesan harta pailit saja. Akan tetapi, Kurator memiliki wewenang dalam menyetujui adanya perubahan anggaran dasar dalam PT yang mengalami kepailitan yang mana RUPS tetap memegang kendali utama dalam penyelenggaraan tersebut, hal ini dapat dilihat daam Pasal 20 ayat (1) UU PT.

Pemberhentian Direksi dapat dilihat dalam UU PT yang menjelaskan bahwa keputusan RUPS yang memegang kendali utama dan kekuasaan ini bersifat inherent dan tidak ada yang dapat mencabut kewenangan ini. Terdapat pula istilah pemberhentian sementara yang diatur dalam Pasal 106 ayat (2) UU PT yang memberikan kewenangan kepada Dewan Komisaris untuk memberhentikan Direksi tetapi hanya untuk sementara kurun waktu tertentu saja.

Dalam hal yang telah dijelaskan tersebut terdapat kronologi serupa di dalam Putusan Mahkamah Konstitusi Nomor 50/PUU-XIII/2015 yang selanjutnya disebut Putusan MK yang mana telah dijelaskan bahwa pemohon telah kehilangan segala-galanya (total loss) di tangan Kurator Pengganti terakhir (Nasrullah Nawawi, SH.MM) yang di luar sepengetahuan pemohon telah mengadakan RUPS sendiri melalui lelang saham persero dan Penetapan Pengadilan Negeri Batam tentang izin mengadakan RUPS sendiri telah mengubah anggaran dasar dan memberhentikan Direksi dan Komisaris, menguasai harta pailit dan operasional perusahaan yang dituangkan dalam Akta Notaris Nomor 1 Tahun 2012 dan pengesahan Menteri Hukum dan Hak Asasi Manusia, mengakhiri kepailitan dengan Putusan Pengadilan Niaga Medan tertanggal 3 November 2014 yang menyatakan memberhentikan Tao Suwarto sebagai Representatif (debitor pailit) sebagaimana dimaksud dalam iklan pengumuman di Sinar Harapan Edisi Jumat tanggal 7 November 2014 yang kesemuanya itu dilakukan oleh Kurator tanpa 
sepengetahuan atau pemberitahuan kepada pemohon. Hal ini disebabkan oleh Kurator yang telah mengadakan RUPS sendiri tanpa sepengetahuan debitor dan mengubah anggaran dasar yang kemudian Kurator tersebut memberhentikan debitor dari kepengurusannya. Selain itu, Panitera Pengadilan Niaga Medan menolak permohonan peninjauan kembali dengan alasan Tato Suwarto selaku Direksi telah diberhentikan sebagai Representatif debitor pailit (perseroan pemohon) oleh karenanya sudah tidak mempunyai legal standing lagi di perseroan pemohon (PT. Batamas Jala Nusantara).

Dalam hal ini, dapat diartikan terjadinya tumpang tindih terhadap kewenangan Kurator yang berhak atau tidak berhak memberhentikan Kurator dikarenakan UUK belum mengatur secara jelas mengenai hal tersebut. UUK mengatur kewenangan Kurator melakukan hal-hal yang menunjang kelancaran pengurusan dan pemberesan harta kekayaan debitor pailit. Untuk memudahkan prosedur dan tata cara pengurusan harta pailit, dibutuhkan kejelasan apakah Kurator juga berwenang memberhentikan Direksi. Untuk keberlangsungan Perseroan agar tidak dilikuidasi dan dapat melunasi utang yang diakibatkan oleh Direksi, maka harus dijelaskan secara tepat mengenai kewenangan Direksi dalam mengurus Perseroan lebih lanjut. Berdasarkan hal tersebut, maka rumusan masalah dalam penelitian ini adalah:

1. Kewenangan Kurator dalam memberhentikan Direksi Perseroan Terbatas dalam kepailitan;

2. Akibat hukum dari tindakan Kurator yang memberhentikan Direksi Perseroan Terbatas dalam kepailitan.

Dalam penelitian hukum ini menggunakan pendekatan undang-undang (statute approach), pendekatan konseptual (conceptual approach), dan pendekatan kasus (case approach). Pendekatan perundang-undangan dilakukan dengan menelaah semua peraturan perundang-undangan yang bersangkutan dengan jaminan penanggungan dan hukum kepailitan. Peraturan yang berkaitan dengan topik bahasan adalah Burgerlijk Webtoek (BW) dan Undang-Undang Nomor 37 Tahun 2004 Tentang Kepailitan (UUK), Undang-Undang Nomor 40 Tahun 
2007 tentang Perseroan Terbatas, Putusan Mahkamah Konstitusi Nomor 50/ PUU-XIII/2015, dan Putusan Pengadilan Niaga Medan Nomor 01/Pailit/2003/ PN. Niaga/Mdn tertanggal 3 November 2014 yang bersumber dari Putusan Mahkamah Konstitusi Nomor 50/PUU-XIII/2015. Bahan hukum yang digunakan juga diperoleh dari seluruh bahan bacaan seperti buku teks, jurnal-jurnal hukum, artikel yang berkaitan dengan permasalahan hukum yang dibahas yakni pemberhentian Direksi oleh Kurator dalam kepailitan.

\section{Kewenangan Kurator dalam memberhentikan Direksi Perseroan Terbatas dalam kepailitan}

Pada Penjelasan Umum UUK, diuraikan pokok-pokok penyempurnaan terhadap Faiilissements Verordening yang merupakan peraturan yang pertama kali mengatur mengenai kepailitan. ${ }^{2}$ Pokok-pokok itu meliputi segi-segi penting yang dinilai perlu untuk mewujudkan penyelesaian masalah utang-piutang secara cepat, adil, terbuka dan efektif, yaitu: ${ }^{3}$

a. Penyempurnaan di sekitar syarat-syarat dan prosedur permintaan pernyataan kepailitan. Termasuk di dalamnya, pemberian kerangka waktu yang pasti bagi pengambilan putusan pernyataan kepailitan, dan lain-lain;

b. Penegasan fungsi kurator dan penyempurnaan yang memungkinkan berfungsinya pemberian jasa-jasa tersebut di samping institusi yang selama ini telah dikenal, yaitu Balai Harta Peninggalan;

c. Penegasan upaya hukum yang dapat diambil terhadap putusan pernyataan kepailitan, bahwa untuk itu dapat langsung diajukan kasasi ke Mahkamah Agung.

Dalam hal adanya perubahan anggaran dasar dalam PT pailit yang diselenggarakan oleh RUPS terutama mengenai pengangkatan, penggantian, dan pemberhentian Anggota Direksi harus mendapat persetujuan dari pihak Kurator.

2 Ridel S. Tumbel, 'Kajian Hukum Tanggung Jawab Direksi terhadap Kerugian Perusahaan Perseroan (Persero)' (2014) 2 Jurnal Hukum Unsrat.[6].

3 ibid.[7]. 
Hal ini dikarenakan PT yang sudah mengalami pailit dan persetujuan Kurator harus dilaksanakan terlebih dahulu sebelum pengambilan keputusan perubahan anggaran dasar guna menghindari terjadinya penolakan oleh Kurator mengenai adanya perubahan anggaran dasar tersebut. Perubahan anggaran dasar ini haruslah diberitahukan kepada Menteri sebagaimana diatur dalam Pasal 21 ayat (3) UU PT. Maka, Kurator tetap tidak berwenang memberhentikan Direksi akan tetapi apabila terdapat perubahan anggaran dasar yang diselenggarakan oleh RUPS perihal pemberhentian Direksi dalam PT pailit, Kurator berhak menyetujui adanya perubahan anggaran dasar tersebut.

Dalam Pasal 69 ayat (2) huruf a UUK diatur bahwa Kurator diperbolehkan melaksanakan tugasnya tanpa diharuskan memperoleh persetujuan terlebih dahulu kepada debitor atau salah satu organ debitor yang mana dalam hal ini Direksi Perseroan Terbatas. Meskipun Kurator tidak diharuskan menyampaikan terlebih dahulu kepada Direksi dalam melaksanakan tugasnya mengenai pengurusan dan/atau pemberesan harta pailit, Kurator tidak memiliki wewenang dalam menyelenggarakan RUPS demi kelancaran pelaksanaannya tersebut. Pasal tersebut mencerminkan bahwa Direksi tidak berwenang dalam melakukan pengurusan dan tidak memiliki penguasaan terhadap hartanya, adanya ketentuan ini dikarenakan agar Direksi kooperatif dengan Kurator.

Dalam poin kedua huruf i alasan dalil Asosiasi Kurator dan Pengurus Indonesia (AKPI) Putusan MK No. 50/PUU-XIII/2015 dijelaskan bahwa hampir bisa dipastikan tidak mungkin debitor pailit akan dengan mudahnya memberikan persetujuan atas semua tindakan Kurator, jika itu sudah menyangkut penguasaan aset apalagi pengalihan aset debitor pailit (dikecualikan terhadap kepailitan sukarela yang dimohonkan sendirioleh debitor pailit). Dengan demikian, walaupun Kurator memiliki wewenang untuk melaksanakan tugasnya tanpa meminta persetujuan terlebih dahulu dari Direksi, Kurator tetap tidak berwenang dalam menyelenggarakan RUPS terutama dalam hal melakukan pemberhentian Direksi. Maka dalam hal ini, Kurator tidak memiliki wewenang dalam menyelenggarakan RUPS sendiri yang mana dalam rangka melakukan pemberhentian terhadap 
Direksi. Pengurusan akan berkait dengan tugas-tugas internal suatu Perseroan Terbatas untuk kepentingan dalam rangka pencapaian maksud dan tujuan Perseroan, sedangkan perwakilan adalah berkaitan dengan tugas Direksi mewakili Perseroan dalam berinteraksi dengan pihak ketiga maupun mewakili di luar dan di dalam Pengadilan. ${ }^{4}$ Abdulkadir Muhammad, Hukum Perusahaan Indonesia (Citra Aditya Bakti 2002).

Di samping tanggung jawab Kurator yang cukup berat tersebut, Kurator juga harus independen serta bebas dari benturan kepentingan (conflict of interest). ${ }^{5}$ Pasal 15 ayat (3) UUK mengatur bahwa yang dimaksud dengan "independen dan tidak mempunyai benturan kepentingan" adalah bahwa kelangsungan keberadaan Kurator tidak tergantung pada debitor atau kreditor, dan Kurator tidak memiliki kepentingan ekonomis yang sama dengan kepentingan ekonomis debitor atau kreditor. ${ }^{6}$

\section{Akibat Hukum Dari Tindakan Kurator Yang Memberhentikan Direksi Perseroan Terbatas Dalam Kepailitan}

Dalam anggaran dasar juga diatur mengenai masa kepengurusan dari masing-masing organ Perseroan misalnya pada tanggal berapa dimulai dan berakhirnya kepengurusan Direksi dan Komisaris dalam menjalankan tugasnya, seperti 3 (tahun) masa kepengurusan dan terhitung mulai RUPS tanggal sekian berakhir. Namun demikian, pada saat masa jabatan Direksi dan atau Komisaris tersebut berakhir, RUPS tidak memutuskan adanya penggantian Direksi dan/atau Komisaris tersebut sehingga dengan lewatnya waktu 3 tahun itu, secara yuridis formal, Perseroan tidak mempunyai anggota Direksi dan atau Komisaris. ${ }^{7}$

Dengan demikian, akan mempersulit keadaan Perseroan yang mengalami kekosongan kepengurusan salah satu organnya yakni Direksi yang diberhentikan sehingga dalam anggaran dasar juga diharuskan mengatur pengangkatan Direksi

\footnotetext{
4 M. Hadi Shubhan, Hukum Kepailitan, Prinsip, Norma, dan Praktik di Pengadilan (Kencana Prenadamedia Group 2015).[226].

5 ibid.

6 ibid.

7 Try Widiyono, Direksi Perseroan Terbatas Edisi Kedua (Ghalia Indonesia 2008).[75].
} 
yang baru. Mengingat pemberhentian anggota Direksi oleh RUPS memerlukan waktu untuk pelaksanaannya, sedangkan kepentingan Perseroan tidak dapat ditunda, Dewan Komisaris sebagai organ pengawas wajar diberikan kewenangan untuk melakukan pemberhentian sementara. ${ }^{8}$

Dalam Pasal 91 UU PT dijelaskan mengenai keputusan yang mengikat (binding decision) di luar RUPS yang dapat ditempuh dengan syarat semua pemegang saham dengan hak suara menyetujui secara tertulis, sistem ini lebih dikenal dengan sebutan circular resolution atau usul keputusan yang diedarkan dan diadakannya pengambilan keputusan ini tanpa adanya proses RUPS secara fisik. Keputusan diambil dengan cara dan syarat: ${ }^{9}$

1) dengan cara mengirimkan secara "tertulis" usul yang akan diputuskan kepada semua pemegang saham;

2) usul tersebut "disetujui" secara tertulis oleh seluruh pemegang saham; dan

3) semua pemegang saham menandatangani usul yang telah disetujui tersebut.

Dalam Pasal 215 UUK dijelaskan bahwa debitor atau ahli waris berhak mengajukan permohonan ke pengadilan mengenai rehabilitasi yang mana rehabilitasi ini digunakan untuk pemulihan nama baik dari debitor yang telah melakukan pemenuhan kewajibannya dengan baik setelah berakhirnya kepailitan sebagaimana dimaksud dalam Pasal 166, Pasal 202, dan Pasal 207. Adapun alasan debitor diberikan hak untuk mengajukan rehabilitasi yaitu: ${ }^{10}$

a. dari sisi internal (debitor) sebagai upaya fresh start bagi debitor dalam semangat melangsungkan usahanya;

b. dari sisi eksternal (pihak ketiga) sebagai upaya untuk mengembalikan kepercayaan pihak ketiga sehubungan dengan adanya putusan pernyataan pailit bagi debitor.

Maka, dengan adanya pemberhentian Direksi oleh Kurator ini menjadikan tidak terlaksananya pemberlakuan Pasal 215 UUK. Dengan demikian, masih

\footnotetext{
8 ibid.[77].

9 M. Yahya Harahap, Hukum Perseroan Terbatas (Sinar Grafika 2009).[423].

10 Serlika Aprita, Hukum Kepailitan dan Penundaan Kewajiban Pembayaran Utang (Perspektif Teori) (Setara Press 2018).[161].
} 
diperlukan adanya kedudukan Direksi apabila hendak melakukan rehabilitasi sebagaimana diatur dalam Pasal 215 UUK. Penegakan Pasal tersebut diatur secara jelas bahwa debitor memiliki hak untuk mengajukan rehabilitasi sehingga Kurator tidak berwenang untuk melakukan pemberhentian terhadap Direksi Perseroan. Tugas Kurator secara rinci antara lain adalah sebagai berikut: ${ }^{11}$

a. Mengumumkan putusan pernyataan pailit, tempat danwaktu penyelenggaraan rapat pertama Kreditor dalam Berita Negara R.I dan dua surat kabar harian yang ditetapkan oleh Hakim Pengawas, dalam jangka waktu paling lambat 5 (lima) hari tanggal putusan pernyataan pailit diterima (Pasal 15 ayat (4) UUK);

b. Mengusahakan keselamatan harta pailit dengan melakukan penyimpanan semua surat, dokumen, uang, perhiasan, efek dan surat-surat berharga lainnya dengan memberikan tanda penerimaan (Pasal 98 UUK);

c. Membuat pencatatan harta pailit paling lambat 2 (dua) hari setelah menerima surat putusan pengangkatannya sebagai Kurator (Pasal 100 UUK), dan setelah itu harus membuat daftar tentang sifat dan jumlah piutang dan beserta jumlah piutang mereka masing-masing (Pasal 102 UUK).

Berkaitan dengan kepailitan badan usaha, maka Kurator dapat melanjutkan usaha debitor yang dinyatakan pailit walaupun terhadap putusan pernyataan pailit tersebut diajukan kasasi atau peninjauan kembali. ${ }^{12}$ Dalam hal Kurator membutuhkan biaya-biaya kepailitan, maka Kurator dapat mengalihkan harta pailit sejauh diperlukan untuk menutup biaya kepailitan atau apabila penahanannya akan mengakibatkan kerugian pada harta pailit, meskipun terhadap putusan pailit diajukan kasasi atau peninjauan kembali. ${ }^{13}$ Kurator dapat mengadakan perdamaian guna mengakhiri suatu perkara yang sedang berjalan atau mencegah timbulnya suatu perkara. ${ }^{14}$ Kurator juga berwenang mengajukan tuntutan hukum atau menghadapi tuntutan hukum atas harta pailit, melakukan

11 Ridwan, 'Kedudukan Kurator dalam Melakukan Eksekusi Budel Pailit yang Berimplikasi pada Pelaporan secara Pidana suatu Kajian Undang-Undang No. 37 Tahun 2004 tentang Kepailitan dan Penundaan Kewajiban Pembayaran Utang', (2018) 3 Ius Constituendum.[206].

${ }^{12}$ M. Hadi Shubhan, Op.Cit.[116].

13 ibid.

14 ibid. 
gugat actio pauliana, yakni gugatan yang meminta kepada Pengadilan untuk membatalkan perbuatan hukum yang dilakukan oleh debitor pailit sebelum adanya putusan pailit. ${ }^{15}$ Laporan mengenai harta pailit serta pelaksanaan tugas yang dilakukan oleh Kurator diharuskan menyampaikan laporan tersebut kepada Hakim Pengawas setiap 3 (tiga) bulan sekali sebagaimana diatur dalam Pasal 74 ayat (1) UUK.

Pertanggungjawaban Direksi yang dituangkan dalam anggaran dasar juga termasuk dalam hal terjadinya kepailitan, hal ini dapat dilihat dalam Pasal 104 ayat (2) UU PT yang menyatakan bahwa anggota Direksi diharuskan tanggung jawab secara renteng jika harta pailit yang digunakan untuk melunasi seluruh tanggung jawab atas kewajiban pembayaran utang tidak terlunasi. Dengan demikian, apabila salah seorang anggota Direksi lalai atau melanggar kewajiban pengurusan secara iktikad baik dan penuh tanggung jawab sesuai dengan lingkup aspekaspek iktikad baik dan pertanggungjawaban pengurusan yang telah disebutkan, maka anggota Direksi sama-sama ikut memikul tanggung jawab secara tanggung renteng terhadap kerugian yang dialami oleh Perseroan. ${ }^{16}$

Maka, ketika dilakukan pemberhentian Direksi dalam proses pengurusan dan/atau pemberesan harta pailit dapat menimbulkan terhalangnya pemenuhan tanggung jawab secara renteng antar anggota Direksi. Dikarenakan masih dibutuhkan adanya kedudukan Direksi dalam pelunasan seluruh kewajiban atas harta pailit tersebut. Terlebih lagi, Kurator tidak memiliki kewenangan sama sekali dalam melakukan pemberhentian Direksi.

Pada dasarnya Kurator hanya berwenang melakukan pengurusan dan/ atau pemberesan terhadap harta pailit sehingga tidak berhak untuk melakukan perbuatan hukum lainnya di luar ranah kewenangannya. Terkait dengan pemberhentian Direksi, Kurator hanya diperbolehkan memberikan persetujuan mengenai adanya perubahan anggaran dasar PT pailit yang diselenggarakan oleh RUPS. Dalam Pasal 15 ayat (3) UUK yang mengatur bahwa Kurator tidak

\footnotetext{
15 ibid.[113].

16 M. Yahya Harahap, Op.Cit.[384].
} 
diperbolehkan menangani lebih dari 3 (tiga) perkara dan harus independen yang tidak mempunyai kebenturan kepentingan terhadap pihak debitor maupun kreditor, jika dilanggar maka tindakan Kurator tersebut tidaklah sah dan dianggap melakukan perbuatan melanggar hukum. Selain itu, apabila terdapat Kurator yang melakukan perbuatan hukum yang tidak sesuai dengan kewenangannya seperti melakukan pemberhentian terhadap Direksi Perseroan Terbatas, hal ini dinilai adanya tindakan sewenang-wenang yang telah dilakukan oleh Kurator.

Kewenangan tetap dimiliki oleh organ-organ Perseroan yang mana dalam hal ini RUPS terkait dengan pemberhentian Direksi PT tersebut. Ketika ditemukan adanya tindakan Kurator yang memberhentikan PT tersebut dapat dinilai bahwa perbuatan hukum tersebut tidak sah dan dinilai Kurator tersebut melakukan perbuatan melanggar hukum. Dalam Pasal 72 UUK dijelaskan bahwa Kurator wajib bertanggung jawab apabila ada kesalahan atau kelalaian yang dilakukan olehnya. Hal ini dikarenakan Kurator hanya memiliki tugas dan wewenang yang terbatas pada pengurusan dan/atau pemberesan harta pailit, tidak adanya kaitan sampai memberhentikan Direksi Perseroan Terbatas dari kepengurusannya serta turut menyelenggarakan RUPS sendiri tanpa adanya pemberitahuan lebih lanjut terhadap debitor pailit yang mana dalam hal ini ialah Direksi PT tersebut.

Maka, ketika dilakukan pemberhentian Direksi dalam proses pengurusan dan/atau pemberesan harta pailit dapat menimbulkan terhalangnya pemenuhan tanggung jawab secara renteng antar anggota Direksi. Dikarenakan masih dibutuhkan adanya kedudukan Direksi dalam pelunasan seluruh kewajiban atas harta pailit tersebut. Kurator hanya berhak menyetujui perlu atau tidaknya perubahan anggaran dasar, akan tetapi kewenangan pemberhentian tetap berada ditangan RUPS.

Dalam Putusan MK No. 50/PUU-XIII/2015 dijelaskan bahwa dari pihak Asosiasi Kurator dan Pengurus Indonesia yang selanjutnya disebut AKPI juga menilai bahwa adanya tindakan Kurator yang termasuk perbuatan sewenangwenang dan melanggar kode etik Kurator yang seharusnya profesional dalam menjalankan tugasnya. Direksi PT yang diberhentikan tersebut dapat meminta 
pertanggungjawaban Kurator sebagai berikut:

a. mengajukan keberatan ke Hakim Pengawas atas tindakan Kurator;

b. melaporkan Kurator ke Dewan Kehormatan Organisasi asal Kurator untuk diperiksa atas dugaan pelanggaran kode etik;

c. meminta pertanggungjawaban Kurator, baik secara perdata maupun pidana. Hal ini tertuang dalam Pasal 77 ayat (1) UUK yang mana debitor pailit dalam hal ini Direksi PT dapat mengajukan surat keberatan kepada Hakim Pengawas terhadap perbuatan yang dilakukan oleh Kurator atau memohon kepada Hakim Pengawas untuk mengeluarkan surat perintah agar Kurator melakukan perbuatan tertentu atau tidak melakukan perbuatan yang sudah direncanakan. Akibat dari adanya Putusan Pengadilan Niaga Medan Nomor 01/Pailit/2003/PN. Niaga/Mdn tertanggal 3 November 2014 yang berisikan pemberhentian terhadap Direksi tersebut ialah Direksi PT tersebut tidak dapat melaksanakan kepengurusannya kembali sebagai Direktur dikarenakan tidak memiliki legal standing dalam PT tersebut.

Dalam Putusan MK No. 50/PUU-XIII/2015 yang menyatakan bahwa Mahkamah Konstitusi menolak permohonan dari Direksi terhadap kejadian yang menimpanya ialah benar, dikarenakan pemohon salah dalam mengajukan keberatan pada Mahkamah Konstitusi. Permasalahan yang dialami oleh Direksi tersebut tidak berkaitan dengan konstitusionalitas norma sebagaimana yang telah diajukan untuk diuji yakni Pasal 69 UUK yang dianggapnya bertentangan dengan Pasal 28F UUD 1945, melainkan kesalahan dalam penerapan norma. Penerapan Pasal 69 UUK ini masih diperlukan karena akan lebih sulit dalam menangani pemberesan jika diharuskan memintapersetujuan debitor yang mana Direksi dalam melakukan pengurusan dan/atau pemberesan harta pailit. Kewenangan dalam Pasal 69 UUK merupakan kewenangan Kurator yang bersifat autoritatif teknis praktis yang berarti kewenangan penuh dari Kurator yang tidak membutuhkan izin atau persetujuan dari pihak debitor atau panitia kreditor. ${ }^{17}$ Hal ini menyebabkan kesulitan dalam melikuidasi dikarenakan bisa 2019).[100].

17 Elyta Ras Ginting, Hukum Kepailitan Pengurusan dan Pemberesan Harta Pailit (Sinar Grafika 
saja Direksi tidak menyetujui langkah yang ditempuh oleh Kurator dengan diawasi oleh Hakim Pengawas.

Penting adanya kerja sama antar seluruh pihak dikarenakan tindakan Kurator dalam melakukan pengurusan dan/atau pemberesan juga demi kepentingan Debitor, bukan hanya kepentingan Kreditor. Kerja sama yang dimaksud antara lain: ${ }^{18}$

1. memberikan seluruh data dan informasi sehubungan dengan harta pailit secara lengkap dan akurat;

2. menyerahkan seluruh kewenangan pengurusan harta pailit dan usahanya pada Kurator dan tidak lagi menjalankan sendiri;

3. jika diminta, membantu Kurator dalam menjalankan tugasnya; dan

4. tidak menghalangi, baik sengaja atau tidak, pelaksanaan tugas Kurator.

Kerja sama yang kurang diantara para pihak juga dapat disebabkan oleh tindakan Kurator, maka oleh sebab itu debitor yang mana Direksi juga dapat mengajukan keberatan yang diakibatkan dari adanya kerugian yang dilakukan oleh Kurator. Debitor pailit diperbolehkan dengan surat permohonan mengajukan perlawanan yang ditujukan kepada Hakim Pengawas terhadap setiap perbuatan yang dilakukan oleh Kurator ataupun meminta dikeluarkannya perintah Hakim, supaya Kurator melakukan suatu perbuatan yang sudah dirancangkan. ${ }^{19}$

Dengan demikian, Direksi dapat mengajukan keberatan yang ditimbulkan dari pemberhentian terhadap dirinya dalam Perseroan yang dilakukan oleh Kurator pada Hakim Pengawas selaku pihak yang mengawasi jalannya Kurator dalam melakukan penanganan terhadap pengurusan dan/atau pemberesan harta pailit. Dalam hal ini, Direksi dapat mengajukan gugatan-gugatan lain terhadap Kurator sebagaimana diatur dalam Pasal 3 ayat (1) UUK. Akan tetapi, dalam hal ini telah terlihat bahwa RUPS merupakan pihak yang memiliki kewenangan penuh terhadap pemberhentian Direksi sehingga Kurator tidak menyelenggarakan RUPS sendiri untuk mengubah anggaran dasar Perseroan terutama dalam hal pemberhentian Direksi, Kurator hanya berwenang menyetujui perlu adanya perubahan anggaran dasar jika PT mengalami kepailitan.

\footnotetext{
${ }_{18}$ Imran Nating, Peranan dan Tanggung Jawab Kurator dalam Pengurusan dan Pemberesan Harta Pailit (RajaGrafindo Persada 2004).[95].

19 ibid.[96].
} 
Dalam hal adanya tindakan Kurator yang sewenang-wenang dalam melakukan pemberhentian terhadap Direksi maka Direksi berhak mengajukan keberatan. Kehadiran Kurator dalam hal Perseroan dinyatakan pailit, menurut Amir Abadi Jusuf tidak meniadakan hak dan kewajiban Direksi sebagai pengurus yang merupakan organ Perseroan, karena Kurator hanya mengambil alih hak untuk mengurus dan membereskan kekayaan perusahaan pailit, dan tidak mengambil oper hak dan kewajiban lainnya. ${ }^{20}$ Ketika terjadi keberatan terhadap putusan pailit, debitor yang mana Direksi dapat mengajukan gugatangugatan lain terhadap Kurator sebagaimana diatur dalam Pasal 3 ayat (1) UUK. Pengajuan tersebut berisikan posita permohonan perihal pengangkatan Kurator yang merugikan Direksi sampai diberhentikan dari jabatannya sehingga tidak memiliki kedudukan sebagai representatif dari PT tersebut karena tidak adanya legal standing dalam melakukan kepengurusan PT.

Berdasarkan UUK, pengadilan yang berwenang untuk mengadili perkara permohonan kepailitan adalah pengadilan yang daerah hukumnya meliputi daerah tempat kedudukan hukum debitor. ${ }^{21}$ Pembentukan pengadilan niaga untuk memeriksa perkara-perkara kepailitan dan juga kelak perkara-perkara perniagaan lainnya berdasarkan peraturan pemerintah, didasarkan atas pertimbangan kecepatan dan efektivitas. ${ }^{22}$ Ketika adanya pelanggaran yang dilakukan oleh Kurator seperti melakukan pemberhentian terhadap Direksi maka Direksi tersebut dapat melakukan pelaporan kepada Dewan Kehormatan selaku pihak yang mengawasi jalannya pelaksanaan kode etik Kurator. Dewan Kehormatan dapat melakukan pemeriksaan terhadap anggota organisasi yang diduga melakukan pelanggaran atas kode etik dan bila dinyatakan bersalah maka Dewan Kehormatan pun berhak menjatuhkan sanksi organisasi. ${ }^{23}$ Dapat disimpulkan bahwa tugas

\footnotetext{
${ }^{20}$ Eylta Ras Ginting, Op.Cit.[253].

21 Ayu Anisaa dan Muhammad Adiguna Bimasakti, Kedudukan Debitor Utama dan Personal Guarantor dalam Permohonan Pernyataan Pailit (Guepedia 2019).[45].

${ }^{22}$ Sutan Remy Sjahdeni, Hukum Kepailitan Memahami Undang-Undang No. 37 Tahun 2004 tentang Kepailitan (Pustaka Utama Grafiti 2009).[141].

${ }^{23}$ Raden Besse Kartoningrat, 'Fungsi Etika Profesi bagi Kurator dalam Menjalankan Tugas', (2016) 21 Perspektif.[121].
} 
Dewan Kehormatan ialah melakukan pengawasan terhadap pelaksanaan kode etik Kurator atau pengawasan internal organisasi Kurator, maksudnya adalah perbuatan yang tidak merugikan pihak lain di luar organisasi, dimana pengawasan terhadap Kurator yang telah ditentukan oleh organisasi Kurator meliputi kewajiban, larangan dan pengecualian yang harus dilakukan oleh para anggota organisasi. ${ }^{24}$ Ketika adanya pelanggaran yang dilakukan oleh Kurator seperti melakukan pemberhentian terhadap Direksi maka Direksi tersebut dapat melakukan pelaporan kepada Dewan Kehormatan selaku pihak yang mengawasi jalannya pelaksanaan kode etik Kurator. Dewan Kehormatan dapat melakukan pemeriksaan terhadap anggota organisasi yang diduga melakukan pelanggaran atas kode etik dan bila dinyatakan bersalah maka Dewan Kehormatan pun berhak menjatuhkan sanksi organisasi. ${ }^{25}$

Hal ini dapat ditemukan dalam Pasal 8 ayat (1) kode etik Profesi Ikatan Kurator dan Pengurus Indonesia (IKAPI) selaku salah satu organisasi Kurator yang mengatur harus adanya pengaduan secara tertulis kepada Dewan Kehormatan dan tidak diperkenankan untuk menggunakan media massa untuk mempublikasi pengaduan tersebut. Lebih lanjut sanksi yang diberikan oleh organisasi IKAPI tersebut sebagaimana diatur dalam Pasal 9 ayat (7) kode etik Profesi IKAPI yakni:
a. teguran secara tertulis;
b. peringatan keras dengan surat;
c. skorsing untuk periode waktu tertentu;
d. pemberhentian sebagai anggota Ikatan.

Dalam hal terjadinya pemberhentian terhadap Direksi ini, maka dapat mengajukan permohonan kasasi atau peninjauan kembali terkait putusan pailit yang merugikan dirinya dan melakukan pelaporan ke Dewan Kehormatan Organisasi asal Kurator untuk diperiksa atas dugaan pelanggaran kode etik.

\footnotetext{
24 ibid.

25 ibid.
} 


\section{Kesimpulan}

Pemberhentian Direksi Perseroan Terbatas haruslah berdasarkan keputusan RUPS yang disertai dengan alasan sebagaimana diatur dalam Pasal 105 ayat (1) UU PT dan pemberhentian sementara dapat dilakukan oleh Dewan Komisaris berdasarkan Pasal 106 ayat (1) UU PT sehingga Kurator tidak memiliki wewenang dalam melakukan pemberhentian terhadap Direksi Perseroan Terbatas jika terjadi kepailitan termasuk menyelenggarakan RUPS sendiri dalam rangka mengubah anggaran dasar dikarenakan kewenangan yang dimiliki oleh Kurator hanya terbatas pada pengurusan dan/atau pemberesan harta pailit (boedel pailit). Terkait mata acara pemberhentian Direksi PT dalam RUPS, Kurator hanya memiliki wewenang dalam menyetujui diperlukan ada atau tidaknya perubahan anggaran dasar mengenai hal tersebut.

Akibat hukum yang terjadi apabila Direksi PT diberhentikan oleh Kurator ialah jabatan Direksi kosong, terhalangnya pemberlakuan rehabilitasi berdasarkan Pasal 215 UUK, terhalangnya pemberlakuan tanggung renteng antar anggota Direksi berdasarkan Pasal 104 UU PT. Upaya yang dapat dilakukan oleh Direksi jika dirinya diberhentikan oleh Kurator dalam kepailitan ialah mengajukan gugatan lain-lain terhadap tindakan Kurator serta melakukan pelaporan ke Dewan Kehormatan Organisasi asal Kurator untuk diperiksa atas dugaan pelanggaran kode etik yang dilakukan oleh Kurator.

\section{Daftar Bacaan}

\section{Buku}

Abdulkadir Muhammad, Hukum Perusahaan Indonesia (Citra Aditya Bakti 2002). Ayu Anisaa, dan Muhammad Adiguna Bimasakti, Kedudukan Debitor Utama dan Personal Guarantor (Guepedia 2019).

Elyta Ras Ginting, Hukum Kepailitan Pengurusan dan Pemberesan Harta Pailit (Sinar Grafika 2019).

Imran Nating, Peranan dan Tanggung Jawab Kurator dalam Pengurusan dan Pemberesan Harta Pailit (RajaGrafindo Persada 2004). 
M. Hadi Shubhan, Hukum Kepailitan, Prinsip, Norma, dan Praktik di Pengadilan (Kencana Prenadamedia Group 2015).

M. Yahya Harahap, Hukum Perseroan Terbatas (Sinar Grafika 2009).

Serlika Aprita, Hukum Kepailitan dan Penundaan Kewajiban Pembayaran Utang (Perspektif Teori) (Setara Press 2018).

Sutan Remy Sjahdeni, Hukum Kepailitan Memahami Undang-Undang No. 37 Tahun 2004 tentang Kepailitan (Pustaka Utama Grafiti 2009).

Try Widiyono, Direksi Perseroan Terbatas Edisi Kedua (Ghalia Indonesia 2008).

Jurnal

Raden Besse Kartoningrat, 'Fungsi Etika Profesi bagi Kurator dalam Menjalankan Tugas', (2016) 21 Perspektif.

Ridel S. Tumbel, ‘Kajian Hukum Tanggung Jawab Direksi terhadap Kerugian Perusahaan Perseroan (Persero)', (2014) 2 Jurnal Hukum Unsrat.

Ridwan, 'Kedudukan Kurator dalam Melakukan Eksekusi Budel Pailit yang Berimplikasi pada Pelaporan secara Pidana suatu Kajian Undang-Undang No.37Tahun 2004 tentang Kepailitan dan Penundaan Kewajiban Pembayaran Utang', (2018) 3 Ius Constituendum.

\section{Perundang-undangan}

Undang-Undang Nomor 37 Tahun 2004 tentang Kepailitan dan Penundaan Kewajiban Pembayaran Utang (Lembaran Negara Republik Indonesia Tahun 2004 Nomor 131, Tambahan Lembaran Negara Republik Indonesia Nomor 4443).

Undang-Undang Nomor 40 Tahun 2007 tentang Perseroan Terbatas (Lembaran Negara Republik Indonesia Tahun 2007 Nomor 106, Tambahan Lembaran Negara Republik Indonesia Nomor 4756).

How to cite: Clara Renny Kartika, 'Kewenangan Kurator Dalam Pemberhentian Direksi Perseroan Terbatas' (2021) Vol. 4 No. 1 Media Iuris. 
--Halaman ini sengaja dibiarkan kosong-- 